University of Nebraska - Lincoln

DigitalCommons@University of Nebraska - Lincoln

Publications, Agencies and Staff of the U.S.

Department of Commerce

U.S. Department of Commerce

2010

\title{
Geographic Variation of Persistent Organic Pollutant Levels in Humpback Whale (Megaptera novaeangliae) Feeding Areas of the North Pacific and North Atlantic
}

\author{
Cristiane T. Elfes \\ Washington Cooperative Fish and Wildlife Research Unit, School of Aquatic and Fishery Sciences, \\ University of Washington \\ Glenn R. Vanblaricom \\ Washington Cooperative Fish and Wildlife Research Unit, School of Aquatic and Fishery Sciences, \\ University of Washington \\ Daryle Boyd \\ National Oceanic and Atmospheric Administration, Northwest Fisheries Science Center, 2725 Montlake \\ Boulevard East, Seattle, Washington 98112 \\ John Calambokidis \\ Cascadia Research Collective, Olympia, Washington \\ Phillip J. Clapham

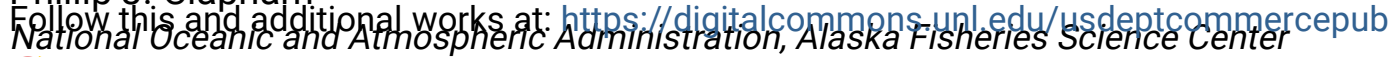 \\ Part of the Environmental Sciences Commons \\ See next page for additional authors
}

Elfes, Cristiane T.; Vanblaricom, Glenn R.; Boyd, Daryle; Calambokidis, John; Clapham, Phillip J.; Pearce, Ronald W.; Robbins, Jooke; Salinas, Juan Carlos; Straley, Janice M.; Wade, Paul R.; and Krahn, Margaret M., "Geographic Variation of Persistent Organic Pollutant Levels in Humpback Whale (Megaptera novaeangliae) Feeding Areas of the North Pacific and North Atlantic" (2010). Publications, Agencies and Staff of the U.S. Department of Commerce. 166.

https://digitalcommons.unl.edu/usdeptcommercepub/166

This Article is brought to you for free and open access by the U.S. Department of Commerce at DigitalCommons@University of Nebraska - Lincoln. It has been accepted for inclusion in Publications, Agencies and Staff of the U.S. Department of Commerce by an authorized administrator of DigitalCommons@University of Nebraska - Lincoln. 


\section{Authors}

Cristiane T. Elfes, Glenn R. Vanblaricom, Daryle Boyd, John Calambokidis, Phillip J. Clapham, Ronald W. Pearce, Jooke Robbins, Juan Carlos Salinas, Janice M. Straley, Paul R. Wade, and Margaret M. Krahn 


\title{
GEOGRAPHIC VARIATION OF PERSISTENT ORGANIC POLLUTANT LEVELS IN HUMPBACK WHALE (MEGAPTERA NOVAEANGLIAE) FEEDING AREAS OF THE NORTH PACIFIC AND NORTH ATLANTIC
}

\author{
Cristiane T. Elfes, ${ }^{*} \dagger$ Glenn R. VanBlaricom, $\dagger$ Daryle Boyd,$\ddagger$ John Calambokidis, $§$ Phillip J. Clapham, $\|$ \\ Ronald W. Pearce, $\ddagger$ Jooke Robbins,\# Juan Carlos Salinas, $†$ Janice M. Straley, $¥ \ddagger$ Paul R. Wade, $\|$ and \\ Margaret M. KRAHNł \\ $\dagger$ Washington Cooperative Fish and Wildlife Research Unit, School of Aquatic and Fishery Sciences, University of Washington, 1122 NE Boat Street, Box \\ 355020, Seattle, Washington 98195, USA \\ $\ddagger$ National Oceanic and Atmospheric Administration, Northwest Fisheries Science Center, 2725 Montlake Boulevard East, Seattle, Washington 98112 \\ §Cascadia Research Collective, $218^{1} \frac{1}{2}$ West Fourth Avenue, Olympia, Washington 98501, USA \\ |National Oceanic and Atmospheric Administration, Alaska Fisheries Science Center, 7600 Sand Point Way Northeast, Seattle, Washington 98115 \\ \#Provincetown Center for Coastal Studies, 5 Holway Avenue, Provincetown, Massachusetts 02657, USA \\ $\dagger †$ National Oceanic and Atmospheric Administration, Southwest Fisheries Science Center, 8604 La Jolla Shores Drive, La Jolla, California 92037

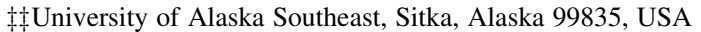

(Submitted 28 May 2009; Returned for Revision 4 September 2009; Accepted 16 November 2009)

\begin{abstract}
Seasonal feeding behavior and high fidelity to feeding areas allow humpback whales (Megaptera novaeangliae) to be used as biological indicators of regional contamination. Biopsy blubber samples from male individuals $(n=67)$ were collected through SPLASH, a multinational research project, in eight North Pacific feeding grounds. Additional male samples $(n=20)$ were collected from one North Atlantic feeding ground. Persistent organic pollutants were measured in the samples and used to assess contaminant distribution in the study areas. North Atlantic (Gulf of Maine) whales were more contaminated than North Pacific whales, showing the highest levels of polychlorinated biphenyls (PCBs), polybrominated diphenyl ethers (PBDEs), and chlordanes. The highest dichlorodiphenyltrichloroethane (DDT) levels were detected in whales feeding off southern California, USA. High-latitude regions were characterized by elevated levels of hexachlorocyclohexanes (HCHs) but generally nondetectable concentrations of PBDEs. Age was shown to have a positive relationship with $\Sigma$ PCBs, 2 DDTs, $\Sigma$ chlordanes, and total percent lipid. Contaminant levels in humpback whales were comparable to other mysticetes and lower than those found in odontocete cetaceans and pinnipeds. Although these concentrations likely do not represent a significant conservation threat, levels in the Gulf of Maine and southern California may warrant further study. Environ. Toxicol. Chem. 2010;29:824-834. (C) 2009 SETAC
\end{abstract}

Keywords-Humpback whale Persistent organic pollutants Polybrominated diphenyl ethers Contaminant variation

Health effects

\section{INTRODUCTION}

Oceans function as sinks in which anthropogenic chemicals such as persistent organic pollutants (POPs) are deposited. Persistent organic pollutants entering the marine environment are readily absorbed by organic matter and taken up by plankton at the base of marine food webs. Bioaccumulation of POPs through the food chain is cause for concern, particularly for long-lived, top-level predators, such as marine mammals and humans. Known consequences of POP contamination in mammals include impaired immunity, increased susceptibility to disease, neurotoxicity, and reproductive impairment [1-3].

Contamination of the marine environment by POPs reflects inputs from both local sources and long-range transport mechanisms. In many developed nations, inputs of well-known POPs such as dichloro diphenyl trichloroethanes (DDTs) and poly-

All Supplemental Data may be found in the online version of this article.

* To whom correspondence may be addressed (celfes@u.washington.edu).

Published online 31 December 2009 in Wiley InterScience (www.interscience.wiley.com). chlorinated biphenyls (PCBs) have decreased as a result of regulation by governmental agencies. Even so, such legacy toxics continue to persist in the environment today. In addition, there is a growing list of emerging contaminants, among them the flame-retardant polybrominated diphenyl ethers (PBDEs). Unlike legacy toxics, PBDEs have not yet been banned in many countries, and concentrations have increased exponentially in some habitats [4,5]. Also of concern is the long-range transport of pollutants, such as atmospheric dispersal by westerly winds from Asia to the eastern North Pacific. This trans-Pacific transfer of pollutants is expected to increase as economic growth continues in Asia [6]. Global-scale processes are also implicated in transporting contaminants to pristine regions such as the Arctic $[7,8]$ and represent a significant regulatory challenge.

Geographic patterns of pollution can be derived effectively from the comparison of levels within a single species, although few such studies have been conducted over a broad scale [9]. Humpback whales (Megaptera novaeangliae) can serve as bioindicators of POP contamination and provide insights into the concentrations of these chemicals in ocean systems. Although they are migratory animals, humpback whales feed 
only during summer months in the productive waters of highlatitude regions. During their migration and winter breeding season in the tropics, humpback whales fast and depend on energy reserves accumulated in their blubber. Additionally, genetic and photoidentification studies give evidence of strong site fidelity of humpback whales to their feeding areas in both the North Pacific and North Atlantic [10-13]. Seasonal feeding behavior and fidelity to feeding regions provide the basis for using humpback whales to better understand regional patterns of marine pollution.

In addition to understanding spatial differences in POP distribution, contaminant data on humpback whales may be able to provide information on population structure and feeding ecology and are important in assessing potential health impacts. Few studies have examined contaminant levels in humpback whales [14-17], and previous work has often been limited to stranded specimens or biopsy samples collected from a few individuals. Here we examine POP levels in free-ranging animals on a large geographic scale. The specific objectives of the present study are to compare contaminant loads in humpback whales from different feeding areas to provide information on the geographic distribution of contaminants, to discuss the biological and ecological factors potentially affecting these loads, and finally to discuss potential health implications for the study populations.

\section{MATERIALS AND METHODS}

\section{Study areas}

North Pacific. Biopsy samples were collected through the Structure of Populations, Levels of Abundance and Status of Humpbacks (SPLASH) project between May and October 2004 (except for three samples from southeastern Alaska, USA, collected in 2003). Samples were collected in seven different feeding areas (Supplemental Data, Table S1), namely, California $(n=10)$, Washington $(n=10)$, southeast Alaska $(n=10)$, northern Gulf of Alaska $(n=8)$, western Gulf of Alaska $(n=9)$, eastern Aleutian Islands $(n=10)$, and Bering Sea $(n=10)$. Because of the large geographic extent from which California samples were obtained, two regions within California were considered: southern California, including samples collected south of Point Sur $\left(36^{\circ} 20^{\prime} \mathrm{N} ; n=5\right)$, and northern California, including individuals sampled north of Point Sur $(n=5)$. The same boundary has been used previously to define subregions for humpback whales that feed off the California coast [18].

North Atlantic. Additional biopsy samples were collected in the Gulf of Maine (Supplemental Data, Table S1) between May and August 2006 (one sample was collected in September, 2005), from two regions: the southwestern (SW) Gulf of Maine, including Stellwagen Bank and the Great South Channel $(n=10)$, and the northeastern (NE) Gulf of Maine, including German Bank and the Bay of Fundy $(n=10)$.

\section{Biopsy samples}

Biopsy samples were collected by approaching target animals and using a crossbow to fire a custom-made tissue collection dart $[19,20]$. Each biopsy dart was fitted with a hollow stainless steel coring tip (length of 4 or $6 \mathrm{~cm}$ ) that collects a small quantity of skin and blubber on impact with the whale. The dart was equipped with a foam stop that limits penetration and causes the dart to recoil and float after sampling. Biopsy samples were stored in 2-ml cryogenic vials, kept on ice or in liquid nitrogen in the field, and later transferred to freezers at $-80^{\circ} \mathrm{C}$ until chemical analyses were done. Before analysis, the blubber portion was excised from the skin using solventrinsed scalpel blades. Lengths of 41 blubber biopsies were measured, and the average length was $1.38 \mathrm{~cm}$.

To facilitate comparisons between feeding areas, only samples from male individuals were used, because females are known to transfer a portion of their contaminant burden to calves during gestation and lactation [21]. All biopsy samples in the present study were determined to be from males through genetic sexing [22-24]. In the Gulf of Maine, sampling intentionally targeted males that were at least $10 \mathrm{y}$ old and therefore considered adults [25]. Exact age was known for individuals first catalogued as dependent calves. The remaining Gulf of Maine whales were assigned a conservative minimum age, assuming that they were born $1 \mathrm{y}$ prior to their first observation. North Pacific animals were of unknown age but were assumed to be adults based on observations in the field. Gulf of Maine sampling also focused on individuals with prior sighting histories that favored either NE or SW study areas.

\section{Contaminant analysis}

Blubber biopsy samples were analyzed for contaminants following laboratory procedures described in detail elsewhere [26]. Briefly, the process involved extraction of approximately $1 \mathrm{~g}$ of blubber tissue mixed with sodium and magnesium sulfates (to remove water) by accelerated solvent extraction (ASE) using $50 \mathrm{ml}$ methylene chloride at $100^{\circ} \mathrm{C}$ and 2,000 psi. The methylene chloride extract was then filtered on a singlestacked silica gel/alumina column and concentrated for further cleanup by size exclusion high-performance liquid chromatography (SEC-HPLC) that separated POPs from bulk lipid and other biogenic material. Finally, the fraction containing POPs was analyzed on a low-resolution quadrupole gas chromatography/mass spectrometry (GC/MS) system equipped with a 60 meter DB-5 GC capillary column.

Blubber samples were analyzed for five contaminant classes: DDTs, PCBs, hexachlorocyclohexanes (HCHs), chlordanes, and PBDEs. Contaminant concentrations are expressed as sum values for each class: $\Sigma$ PCB is the sum of $40 \mathrm{PCB}$ congeners (refer to Sloan et al. [26] for complete list); $\Sigma$ DDT is the sum of $o, p^{\prime}$-dichlorodiphenyldichloroethane (DDD), $p, p^{\prime}$ DDD, $p, p^{\prime}$-dichlorodiphenyldichloroethylene (DDE), $o, p^{\prime}$ DDE, $o, p^{\prime}$-DDT, and $p, p^{\prime}$-DDT; $\Sigma$ chlordanes is the sum of oxychlordane, $\gamma$-chlordane, nona-III-chlordane, $\alpha$-chlordane, trans-nonachlor, and cis-nonachlor; $\Sigma$ HCHs is the sum of $\alpha$-, $\beta$-, and $\gamma-\mathrm{HCH}$ isomers; and $\Sigma$ PBDEs is the sum of congeners 28, 47, 49, 66, 85, 99, 100, 153, 154, and 183. Contaminant values are reported as lipid weight concentrations in nanograms per gram (ppb).

Quality assurance (QA) measures were incorporated into each batch of up to 12 samples according to the Environmental Assessment Program Quality Assurance Plan [27]. Each batch of samples included a method blank and a Standard Reference Material (SRMs 1945 and 1947) from the National Institute of Standards and Technology. Internal standards were added to the samples before extraction to monitor for losses during sample preparation and cleanup. Criteria were met for all QA parameters. 


\section{Lipid analysis}

Blubber samples were analyzed for total percent lipid (relative to sample wet weights) using a thin-layer chromatography/flame ionization detection (TLC/FID) method [28]. Five lipid classes (i.e., wax esters/sterol esters, triglycerides, free fatty acids, cholesterols, and phospholipids) were analyzed on Chromarod type S-III silica rods using a 60:10:0.02 hexane:diethyl ether:formic acid (v/v/v) solvent system and measured with an Iatroscan MK-6s (Shell). The Iatroscan was operated with a hydrogen flow rate of $160 \mathrm{ml} / \mathrm{min}$ and air flow of $2,000 \mathrm{ml} / \mathrm{min}$. A four-point linear external calibration was used for quantification. Duplicate TLC/FID analyses were performed for each sample extract, and mean values are reported. Percent total lipids were calculated by adding the wet weight concentrations of the five lipid classes measured.

\section{Statistical analysis}

Prior to all statistical calculations, both contaminant and total lipid concentration data were tested for normality. Raw values for total lipid concentration were normally distributed. $\log _{10}$-transformation improved normality of the contaminant data and was used for all subsequent calculations. In some samples, contaminant concentration values fell below the level of quantification (LOQ). For statistical purposes, a random value was chosen between zero and the lowest LOQ value for analytes within that class [29]. Means reported here are geometric means, calculated using only samples with detectable concentrations. The standard error of the mean (SE) was calculated in $\log _{\mathrm{e}}$ space and back-transformed to determine the coefficient of variation $(C V)$ in real space using the formula: $C V=\mathrm{e}^{\mathrm{SE}}-1$. The $\mathrm{SE}$ in real space was then calculated as the geometric mean times the $C V$.

Mean percent total lipid and concentrations of each pollutant class were tested for significant differences by geographic areas using one-way analysis of variance. When significant differences were found, pairwise comparisons were examined using the Tukey-Kramer honestly significant difference test (Tukey HSD). Comparisons between the two regions within California and between the two regions within the Gulf of Maine were also analyzed separately using Welch's two-sample $t$ test, which does not assume equal variance.

For samples from the Gulf of Maine, correlations between contaminant concentration and animal age and between total lipid concentration and age were examined using linear least squares regression. For all tests, statistical significance was reported for $p<0.05$ unless otherwise noted. Statistical tests were performed using $\mathrm{R}$ Program Language (ver 2.4.0; $\mathrm{R}$ Development Core Team, 2006).

\section{RESULTS}

\section{Contaminant concentrations}

For all biopsy samples analyzed $(n=87)$, recoveries of the surrogate standards ranged from 62 to $113 \%$, with an average of $98 \pm 9 \%$. Mean concentrations for all POP classes by region are presented in Table 1.

In general, contaminant concentrations of the North Atlantic study regions were higher than those of the North Pacific (Table 1). Humpback blubber samples from the Gulf of Maine had the highest mean values for $\Sigma$ PCBs, $\Sigma$ chlordanes, and
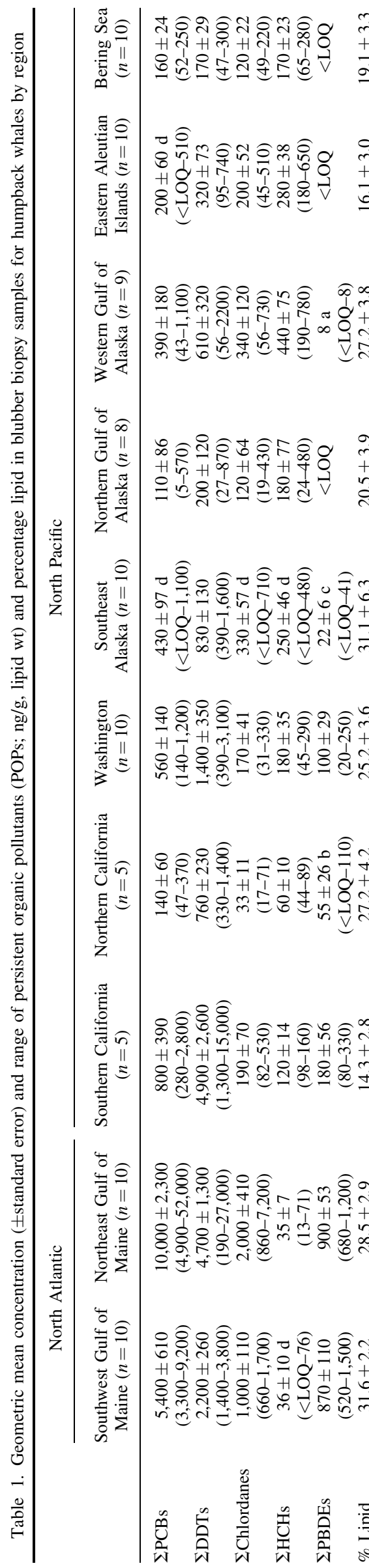

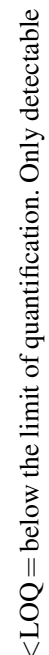

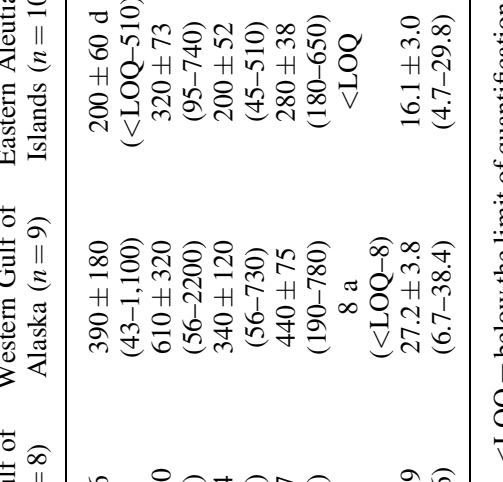

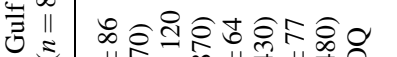

可施

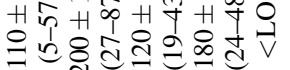

ले के

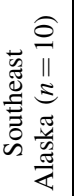

$\approx$

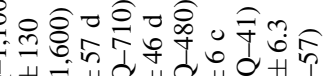

$\begin{array}{lll}0 & 0 \\ 0 & 0 & 0\end{array}$ 守

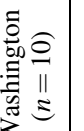

ㅇํㅇำ

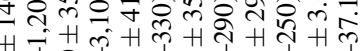

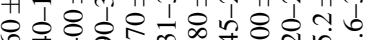

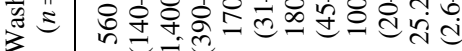

:

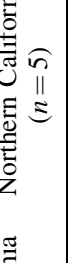

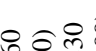

$\widehat{8}=$

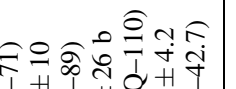

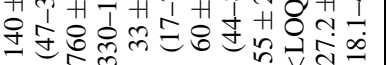

过震

(1)

合

ㅇㅎㅇ

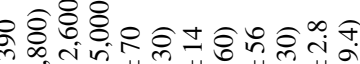

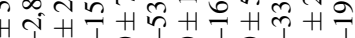

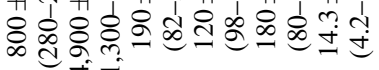
+

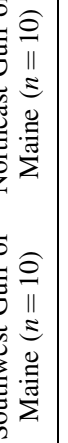

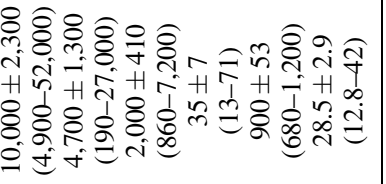


¿PBDEs. Levels of $\Sigma$ PCBs and $\Sigma$ chlordanes from Gulf of Maine whales were significantly higher than those from any North Pacific region, with mean values one to two orders of magnitude greater. The $\Sigma$ DDT levels were also high, with mean values in the NE Gulf of Maine only slightly less than those detected in southern California. Contrary to the results observed with all other contaminant classes, $\Sigma \mathrm{HCH}$ levels in North Atlantic whales were lower than in the North Pacific whales.

The two North Atlantic areas were examined separately using Welch's two-sample $t$ test (Fig. 1). Humpback blubber samples collected in the NE Gulf of Maine had significantly higher levels of $\Sigma$ PCBs, $\Sigma$ DDTs, and $\Sigma$ chlordanes, with mean values approximately double those of the SW Gulf of Maine. Concentrations of $\Sigma$ PBDEs and $\Sigma$ HCHs were similar in the two regions.

In the North Pacific, distribution patterns of POPs varied by class (Fig. 2). Levels of $\Sigma$ PCBs, $\Sigma$ DDTs, and $\Sigma$ PBDEs were greater along the U.S. West Coast, with highest concentrations detected in southern California and Washington whales. Both $\Sigma$ PCBs and $\Sigma$ DDTs were ubiquitous in humpbacks throughout the North Pacific study regions. In contrast, $\Sigma$ PBDEs were not detected in whales from remote regions, such as northern Gulf of Alaska, eastern Aleutian Islands, or Bering Sea, and were detected in only a single sample in the western Gulf of Alaska. A different pattern was observed for $\Sigma$ chlordanes and $\Sigma \mathrm{HCHs}$, with highest concentrations detected in the western Gulf of Alaska whales and those from other high-latitude regions, including southeast Alaska and eastern Aleutian Islands.

Concentrations of $\Sigma$ DDTs were exceptionally high in humpback blubber samples collected off southern California, and levels decreased in samples collected to the north and west along the Pacific Rim. When the two California regions were compared (Fig. 3), mean concentrations of all POP classes were significantly higher in southern California whales (Welch's two-sample $t$-test, $p<0.05)$. This difference was most significant for $\Sigma$ DDTs, with mean concentrations in southern California samples more than six times those of northern California.

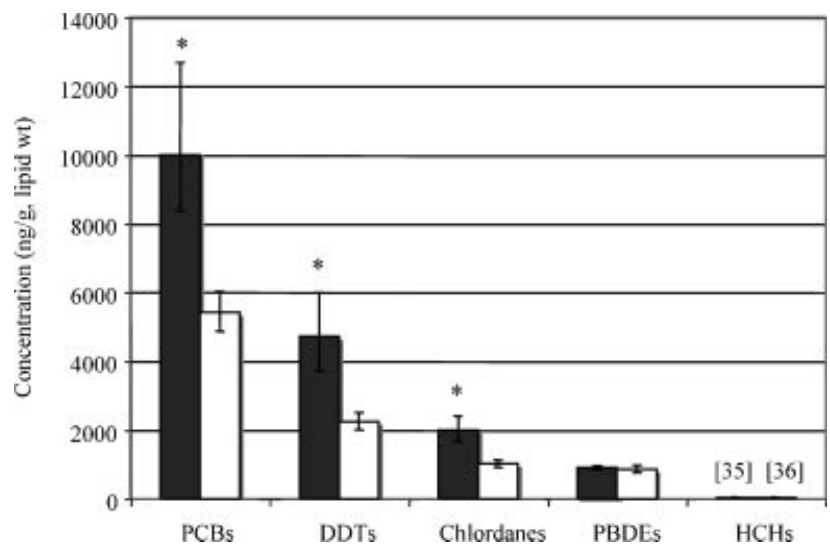

Fig. 1. Comparison of geometric mean concentrations ( \pm standard error) for contaminants between the Northeastern Gulf of Maine (NE GOM; solid bars) and Southwestern Gulf of Maine (SW GOM; open bars). Bars with asterisks have statistically higher values than comparison bars within pairs (Welch's $t$ test, $p<0.05)$. PCBs $=$ polychlorinated biphenyls; DDTs $=$ dichloro diphenyl trichloroethanes; PBDEs = polybrominated diphenyl ethers; $\mathrm{HCHs}=$ hexachlorocyclohexanes. The numbers in brackets refer to the contaminant concentrations for those bars (in $\mathrm{ng} / \mathrm{g}$, lipid wt).

\section{Lipid concentrations}

Mean percent total lipid for humpback blubber collected in all regions ranged from 14.3 to $31.6 \%$ (Table 1). The highest total lipid concentrations (over $30 \%$ ) were detected in humpbacks from the SW Gulf of Maine and southeast Alaska, whereas the lowest lipid levels (below 20\%) were found in humpbacks from southern California, the eastern Aleutian Islands, and the Bering Sea. Differences in mean total lipid concentrations among regions were not statistically significant.

\section{Influence of age}

For Gulf of Maine whales, linear least squares regression revealed a positive correlation between age and $\Sigma$ PCBs $\left(R^{2}=0.56, p<0.001\right)$, LDDTs $\left(R^{2}=0.65, p<0.001\right)$, and $\Sigma$ chlordanes $\left(R^{2}=0.70, p<0.001\right)$, whereas $\Sigma$ PBDEs and $\Sigma$ HCHs did not correlate well with age (Fig. 4). Total percentage lipid was negatively correlated with age $\left(R^{2}=0.27\right.$ $p<0.001$; Fig. 4).

\section{DISCUSSION}

\section{Geographic variation of contaminants}

Blubber from humpback whales biopsied in the North Atlantic and North Pacific study areas showed marked differences in POP contamination. The highest concentrations of $\Sigma$ PCBs, $\Sigma$ chlordanes, and $\Sigma$ PBDEs, as well as high $\Sigma$ DDT levels, were detected in the Gulf of Maine humpbacks, likely a result of greater industrialization and the larger human population density of the eastern United States compared with other regions sampled [30]. For example, total usage of PCBs was shown to be higher on the eastern side of the United States [31]. In contrast, North Pacific samples showed higher $\Sigma \mathrm{HCH}$ values, likely a result of transport from the main user countries in Asia. Although $\mathrm{HCH}$ is currently banned in China, it is estimated that over 4 million tons of technical $\mathrm{HCH}$ were produced there from 1952 to 1983 , accounting for almost half the total global usage. India also has a legacy of extensive use of $\mathrm{HCH}$, comprising an estimated 1 million tons before 1995 [32,33].

The highest $\Sigma \mathrm{HCH}$ levels were detected in humpbacks from the western Gulf of Alaska, and, in general, concentrations were greater in high-latitude regions. A similar pattern was observed previously in samples taken from surface seawater north of $40^{\circ} \mathrm{N}$, including the Bering Sea, Gulf of Alaska, and northern North Pacific [34]. Higher HCH levels were also detected in odontocete cetaceans from cold and temperate waters compared with animals from the tropics [35]. Transport of HCHs to high latitude may occur through different mechanisms depending on the isomer, including cold condensation [8] and ocean currents [36]. In general, HCHs have a greater tendency to be transported to high latitudes compared with the other POP classes analyzed.

Although PBDEs have been increasing exponentially in some Arctic biota [5], these chemicals were not detected in humpback whales sampled in the northern Gulf of Alaska, eastern Aleutian Islands, or Bering Sea and were found only at low concentrations in one sample from the western Gulf of Alaska. Thus, it appears that humpback whales feeding in remote regions have not yet been significantly exposed to this pollutant class compared with those in proximity to industrialized coastal areas of North America. In areas where $\Sigma$ PBDEs were detected, concentrations were still lower than those of 


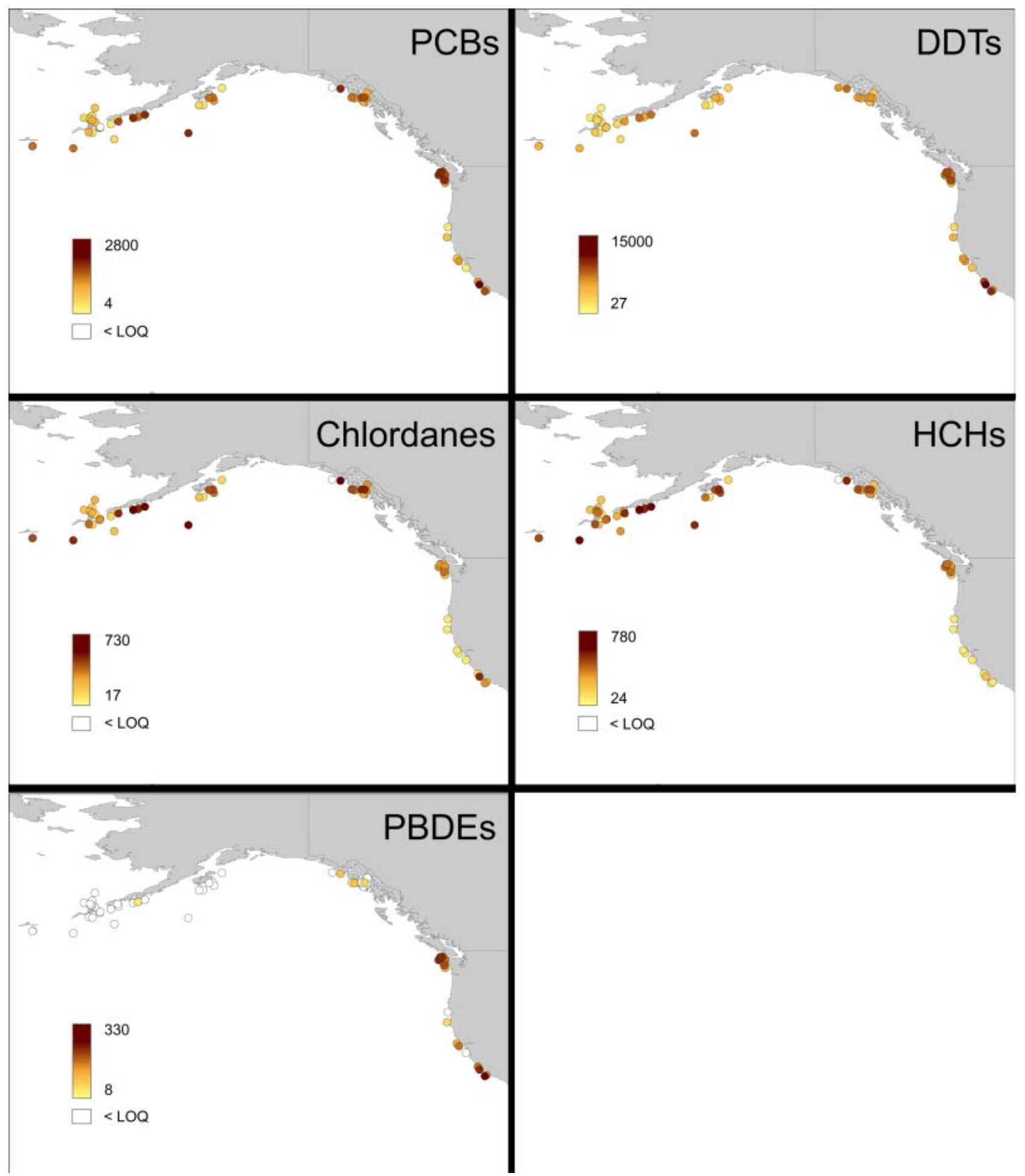

Fig. 2. Contaminant distribution patterns for biopsied humpback whales in the North Pacific. The range of concentrations (ng/g, lipid wt) for each class is shown. Samples in white had concentrations below the limits of quantification $(<\mathrm{LOQ})$. PCBs = polychlorinated biphenyls; DDTs = dichloro diphenyl trichloroethanes; $\mathrm{HCHs}=$ hexachlorocyclohexanes; PBDEs = polybrominated diphenyl ethers. [Color figure can be seen in the online version of this article, available at www. interscience.wiley.com.]

¿PCBs and $\Sigma$ DDTs. However, PBDE levels should continue to be monitored, because these compounds remain largely unregulated in the United States and Canada. Polybrominated diphenyl ethers have been reported in blubber biopsies taken from resident killer whales in the Gulf of Alaska and Aleutian Islands, demonstrating that these contaminants are present in the environment and accumulating at detectable concentrations at higher trophic levels [37].

The comparison between humpbacks from southern and northern California revealed significantly higher contamination in the south for all POP classes, even with a low sample size ( $n=5$ for both regions). This is not surprising, as the Southern 


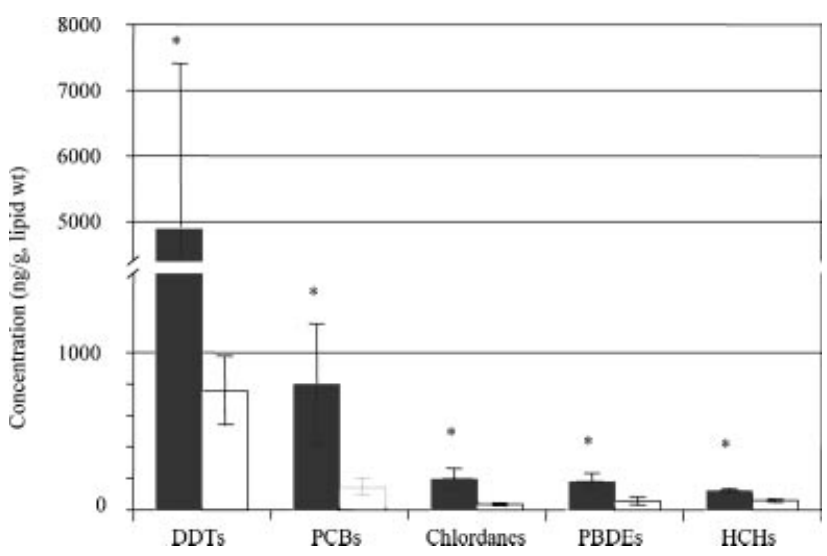

Fig. 3. Comparison of geometric mean concentrations ( \pm standard error) for contaminants between southern California, USA (solid bars), and northern California (open bars). Bars with asterisks have statistically higher values than comparison bars within pairs (Welch's $t$ test, $p<0.05$ ). DDTs = dichlorodiphenyltrichloroethanes; $\mathrm{PCBs}=$ polychlorinated biphenyls; PBDEs $=$ polybrominated diphenyl ethers $; \mathrm{HCHs}=$ hexachlorocyclohexanes.

California Bight is impacted by pollutant inputs from highly urbanized areas, including treated municipal and industrial wastewater and stormwater discharges [38]. The difference between the two areas was most significant for LDDTs, with mean levels in the whales from the south more than six times greater than those from the north. Until 1971, the Palos Verdes Shelf near Los Angeles received inputs of approximately 1,800 metric tons of DDT per year discharged illegally by the Montrose Chemical Corporation [39]. The contamination was so severe that this area has now been designated a Superfund site by the U.S. Environmental Protection Agency.

In general, humpback whales appear to be good bioindicators, reflecting what is known about environmental levels of contaminants. This lends further support to studies of humpback whale population structure, which have shown strong site fidelity of whales to feeding areas [10-13]. For example, whales that feed off the coasts of California, Oregon, and Washington are thought to form a relatively distinct feeding aggregation [10]. The significant differences in contaminant levels between the southern and northern California regions provide evidence that animals may show site fidelity to specific feeding locations, even within the relatively distinct California-Oregon-Washington region. This is consistent with previous research describing overlapping migratory corridors of whales off the California coast [18]. Whales that overwinter in Central America were typically resighted in southern California feeding grounds, whereas those overwintering in mainland Mexico and Baja California were seen feeding primarily in northern California. Substructuring and fidelity of humpback whales to smaller areas within a feeding ground has also been observed in the North Atlantic [13]. Previous work examining PCB/DDE ratios in harbor porpoise (Phocoena phocoena) along the U.S. West Coast also found distinct regional patterns in contaminants [40].

The potential exists, therefore, for using contaminants as chemical markers to distinguish between whales that feed in different regions. This approach has been used previously to understand population structure in harbor porpoise [40,41] as well as feeding regions for eastern North Pacific killer whales [37]. Identification of whales by feeding area could assist in
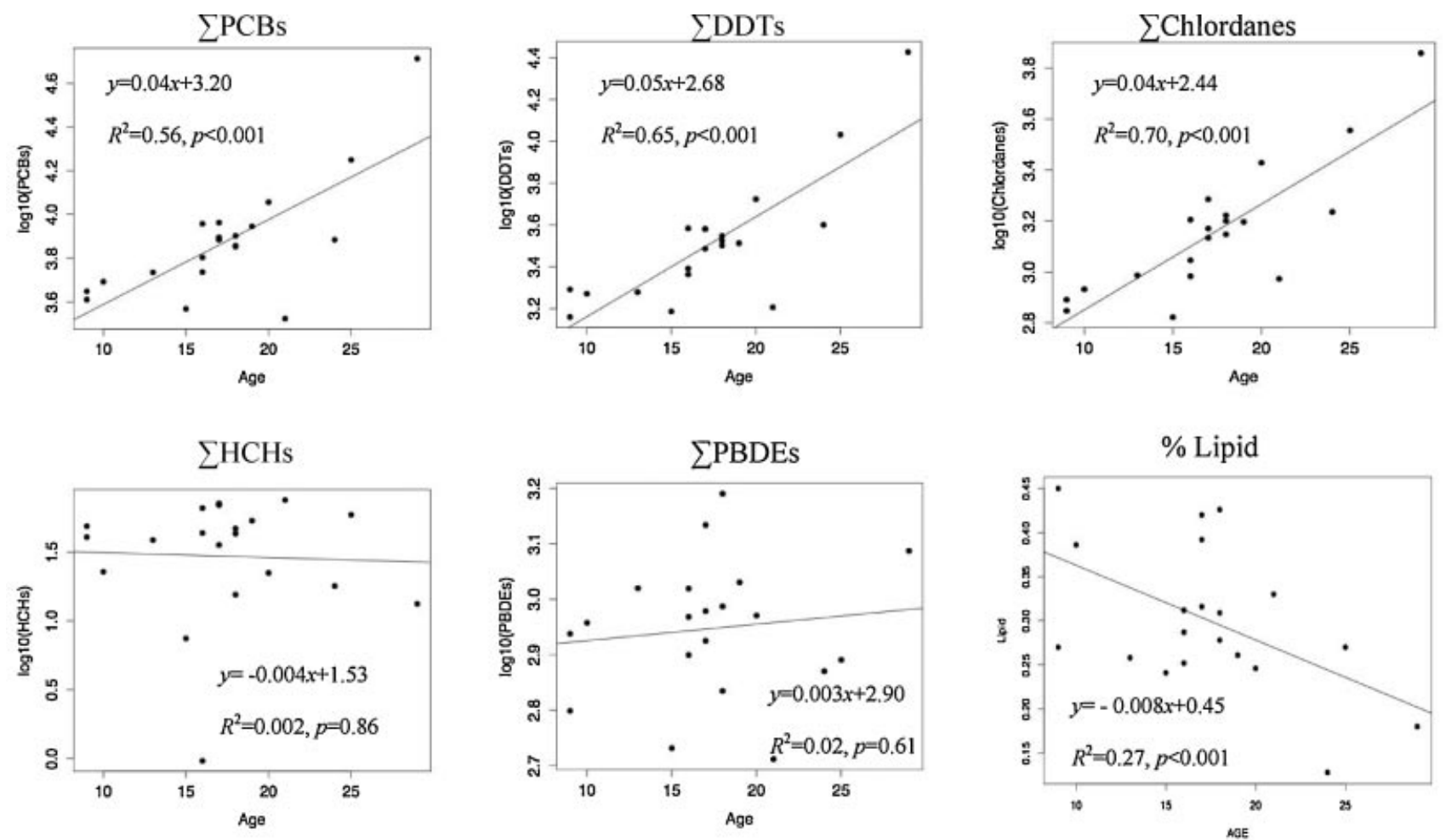

Fig. 4. Regression analyses of age in years ( $x$ axis) versus log-transformed contaminant concentrations (ng/g, lipid wt) and percentage total lipid ( $y$ axis) of blubber biopsies from Gulf of Maine humpback whales. Trend lines, equations, and statistical significance are shown in each graph. PCBs = polychlorinated biphenyls; DDTs = dichlorodiphenyltrichloroethanes; HCHs = hexachlorocyclohexanes; PBDEs = polybrominated diphenyl ethers. 
determining the migratory destinations of whales sampled in their breeding areas.

\section{Ecological and biological factors affecting contaminant loads}

Prey. Differences in prey composition are a key consideration when interpreting POP loads. Contaminant intake in marine mammals occurs primarily through food [42]. Divergent diet was shown to have profound effects on POP concentrations and patterns in grizzly bears (Ursus arctos horribilis) [43]. Similarly, differences in contaminant concentrations, patterns, and ratios have helped to elucidate diet composition of the three eastern North Pacific killer whale (Orcinus orca) ecotypes $[37,44]$.

Although considered generalist feeders, humpback whales may show regional prey preferences, with potential effects on contaminant residues. We hypothesize that differences in prey may have influenced the spatial patterns in contaminant levels observed in Gulf of Maine whales. The detection of significantly higher concentrations of $\Sigma$ PCBs, $\Sigma$ DDTs, and $\Sigma$ chlordanes in NE compared with SW Gulf of Maine animals is inconsistent with information about environmental levels of organic contaminants in the Gulf of Maine. Long-term monitoring studies of blue mussels (Mytilus edulis) have shown a gradient of POP concentrations that increases from north to south [45]. Similarly, $\Sigma$ PCBs levels in zooplankton were shown to be higher in Cape Cod Bay compared with the Bay of Fundy [46]. Thus, higher levels would be expected in SW Gulf of Maine whales, which feed closer to areas of high human population density, large rivers, and sewage treatment outflow for the city of Boston.

Elevated POP concentrations in the NE Gulf of Maine group might result from feeding on higher trophic level prey compared with SW animals or prey originating from a contaminated source area. Although limited information is available regarding prey composition of whales feeding in the NE (Bay of Fundy), they are thought to feed mainly on euphausiids (Meganyctiphanes norvegica) and herring (Clupea harengus) [47]. For animals feeding in the SW Gulf of Maine, particularly on Stellwagen Bank, sand lance (Ammodytes spp.) are thought to be among the primary prey species [48-50]. Humpback whale aggregations in the SW Gulf of Maine were shown to be significantly correlated with areas of sand lance abundance [48].

Lipid content of humpback whale prey species may influence overall contaminant uptake. Mean lipid content of sand lance $(2.9 \%$, wet wt) was estimated to be less than one-fourth the lipid content of herring (13.7\%, wet wt) [51]. Values for the euphausiid $M$. norvegica ranged between 13 and 34\% (dry wt) [52]. Thus, the relatively low lipid content of sand lance in comparison with other prey may explain why contaminant concentrations were lower in SW Gulf of Maine animals. Direct analyses of contaminant loads in prey samples are needed to better understand the bioaccumulation of POPs in Gulf of Maine humpback whales.

In the North Pacific, diet composition of humpback whales may also vary geographically. However, dietary data are limited because of the relative inaccessibility of many of the study regions. Available information stems mainly from stomach contents of animals that were caught by Japanese whalers, as well as from limited areas in which dedicated studies of hump- back whales have occurred (e.g., [53]). Whaling records report that $77.3 \%$ of stomachs examined for humpback whales caught by the Japanese between 1952 and 1971 contained euphausiids exclusively [54]. In contrast, humpback whales tagged near Kodiak, Alaska, were shown to target schools of capelin (Mallotus villosus), even when concentrations of other prey such as pollock (Theragra chalcogramma) and euphausiids (Thysanoessa spp.) were available [55].

For the most part, POP levels observed for whales in the present study were congruent with previous information on contaminant distribution in the North Pacific [9]. However, blubber from humpbacks from the western Gulf of Alaska (Shumagin Islands) consistently showed POP levels higher than those found for whales from neighboring areas (northern Gulf of Alaska and eastern Aleutian Islands). Potential sources of contaminants to Steller sea lions (Eumetopias jubatus) throughout the Gulf of Alaska and Aleutian Islands have been examined [56], but no specific point sources are known that could account for the higher levels observed. Stable nitrogen isotope analyses [57] do not provide support for the hypothesis that humpback whales in the Shumagin Islands feed at higher trophic levels compared with whales from adjoining areas, thereby experiencing greater bioaccumulation of POPs. Mean trophic level for western Gulf of Alaska samples was similar to that of eastern Aleutian Islands and Bering Sea; highest trophic level values in the North Pacific were found for animals sampled in the northern Gulf of Alaska and along the west coasts of the United States and Canada [57]. Therefore, regional differences in prey do not appear to explain the higher levels observed in western Gulf of Alaska animals.

Age. Age can be another important factor influencing contaminant burdens. Samples from Gulf of Maine whales showed an increase in concentrations of $\Sigma$ PCBs, $\Sigma$ DDTs, and $\Sigma$ chlordanes with known or minimum age. The relationship was close to linear, with $R^{2}$ values ranging from 0.56 to 0.70 , suggesting a continual uptake of contaminants at rates greater than the animal's capacity for metabolism and elimination.

Significant positive correlations between age and $\Sigma$ PCBs, $\Sigma$ DDTs, and $\Sigma$ chlordanes have also been found in male bowhead whales (Balaena mysticetus) [58,59] and male North Atlantic right whales (Eubalaena glacialis) [46]. In northeast Atlantic minke whales (Balaenoptera acutorostrata), significantly higher concentrations of the same three contaminant classes were found in mature males compared with juvenile males [60]. Similarly, both total estimated body burden and concentrations (lipid wt) of $\Sigma$ DDTs and $\Sigma$ PCBs were positively correlated with age in male fin whales (Balaenoptera physalus) but tended to reach an asymptote in older mature individuals $[21,61]$. A leveling off of contaminant loads with increasing age was not observed for humpbacks in the present study. However, exact age was not known for several individuals, and the life span of this species has yet to be established. Thus, although the present study included animals with long-documented sighting histories, it did not necessarily encompass the oldest animals in the population.

No significant correlation was found between either $\Sigma \mathrm{HCHs}$ or $\Sigma$ PBDEs and age. Previous investigations have shown similar results when $\mathrm{\Sigma} H \mathrm{HCHs}$ were plotted against age for bowhead whales [59]. Hexachlorocyclohexanes (particularly 
$\gamma-\mathrm{HCH})$ are more water soluble and volatile compared with other contaminants and may, therefore, bioaccumulate to a lesser degree [62]. Additionally, marine mammals are thought to metabolize $\alpha$ - and $\gamma$-HCHs more readily, although the ability of different species to metabolize a given isomer may be variable [62]. The makeup of technical $\mathrm{HCH}$ over time has also changed; it is composed of an increasing percentage of the more polar $\gamma-\mathrm{HCH}$ [63], with consequent reduction in the global output of the more lipophilic isomer $\beta-\mathrm{HCH}$.

The present study is the first to examine the relationship of PBDEs with age in a mysticete. As with $\Sigma \mathrm{HCHs}$, no significant relationship was found. In contrast to $\mathrm{HCHs}$, the chemistry of PBDEs is well-suited for bioaccumulation. In addition, whales are thought to have limited metabolic capacity for PBDE compounds [64]. The relationship between PBDEs and age may be confounded by the fact that older animals have only recently been exposed to this contaminant compared with other POPs.

Apart from the previously discussed differences in prey, age might also have influenced the significantly higher concentrations of $\Sigma$ PCBs, $\Sigma$ DDTs, and $\Sigma$ chlordanes observed in NE Gulf of Maine samples, insofar as these were also the three classes for which a bioaccumulative trend was shown. Interpretation of an age effect is confounded by the fact that only minimum age was known for some sampled animals (Supplemental Data, Table S1). Particularly high contaminant levels were associated with two NE Gulf of Maine whales of unknown exact age, specifically, samples CCS2006-053 (minimum age 29) and CCS2006-061 (minimum age 25). However, when these two samples were removed from the analysis, concentrations of ¿PCBs, $\Sigma$ DDTs, and $\Sigma$ chlordanes remained significantly higher in the NE Gulf of Maine group (Welch's $t$ test, $p<0.02$ in all cases). An age effect is further supported by evidence of demographic stratification within the Gulf of Maine, with NE Gulf of Maine whales being older on average than whales in the SW Gulf of Maine [65].

Although age data were not available for North Pacific animals, the elevated concentration of POPs in western Gulf of Alaska (WGA) samples, compared with neighboring regions, could be a reflection of a higher proportion of older individuals in the WGA sample.

Age was also shown to have a significant effect on total percent lipid in blubber biopsies. In this case, total percent lipid showed a gradual decrease with increasing age $(\sim 0.8 \%$ reduction in lipid per year of age). A decrease in lipid with age was also observed in the blubber of male fin whales [66]. This pattern may be explained by an overall decrease in fitness of older individuals, with resulting changes in lipid composition of blubber.

The bioaccumulation of contaminants with age (as observed for $\Sigma$ PCBs, $\Sigma$ DDTs, and $\Sigma$ chlordanes) is a significant factor and should be taken into account when interpreting humpback whale contaminant burdens. For example, if the linear regression equation is used to estimate $\mathrm{SPCB}$ loads, an increase in $10 \mathrm{y}$ of age in a humpback whale may account for a doubling of the animal's contaminant burden. Although a decline in percent total lipid occurred with age, the rate of reduction was gradual and is likely a separate and much less significant factor in determining blubber biopsy contaminant levels.

\section{Health risks}

Contaminant data from the present study are the most comprehensive thus far collected for humpback whales. Previous reports from the literature include two stranded animals from the eastern United States and Canada [14], two biopsy samples from free-ranging animals in the West Indies [14], two stranded animals from southeast Alaska [15], and 33 biopsy samples from free-ranging animals in the Gulf of Saint Lawrence $[16,17]$.

Analytical methods, number of analytes reported, and normalization of data (wet wt or lipid wt basis) vary in published information. However, some general patterns are apparent. Data from Gulf of Saint Lawrence whales (including individuals of both sexes as well as calves) [16,17] were compared with those from the Gulf of Maine, because of their geographic proximity. Mean $\Sigma$ chlordane and $\Sigma$ DDT values from the Gulf of Saint Lawrence most closely resembled means for the SW Gulf of Maine. Mean $\Sigma$ PCBs were generally higher in the Gulf of Maine, whereas mean $\Sigma \mathrm{HCH}$ levels were higher in Gulf of Saint Lawrence, which is consistent with the latitudinal pattern found in our study.

Contaminant levels in two stranded humpback whales from the eastern United States and Canada [14] were previously considered to be the highest reported for humpback whales. A pregnant female killed in a Nova Scotia fishery had levels of 23,100 ppb and 5,400 ppb (wet wt) for $\Sigma$ DDTs and $\Sigma$ PCBs, respectively. A juvenile male found stranded in New Jersey had a $\Sigma$ DDT concentration of 7,600 ppb (wet wt) and a $\Sigma$ PCB concentration of $6,000 \mathrm{ppb}$ (wet wt). High concentrations in these samples may not be representative of the population if the sampled animals were in a compromised state of health or if the carcasses were in poor condition. Even so, it is noted that, although these animals were sampled more than three decades ago, levels of $\Sigma$ PCBs were comparable to those found in the present study for Gulf of Maine humpbacks. The $\Sigma$ DDT level of $23,100 \mathrm{ppb}$ is high compared with the range of wet weight concentrations for the present study (Supplemental Data, Table S2) but falls within the range of lipid weight concentrations detected in the NE Gulf of Maine (Table 1). This suggests that, although these contaminants have been banned in the United States and Canada since the 1970s, current levels in humpback whales may not reflect a significant decrease in exposure.

In the North Pacific, a single study has reported on POP contamination in humpback whales [15]. Levels of $\Sigma$ PCB in one stranded female ( $87 \mathrm{ppb}$, wet wt) and one stranded male (130 ppb, wet wt) were within the range of values observed in humpback blubber samples for the southeast Alaska region.

Establishing a link between POP levels and population effects in baleen whales is difficult, because virtually no information is available on diagnostic levels for direct mortality, suppression of immune function, or reduced reproductive success for animals in the wild. Inferences are typically made from studies of other mammals in laboratory settings or semifield conditions. A review of the contaminant literature on mysticetes found little evidence for organochlorine impacts on baleen whale populations [67]. The data presented here are consistent with the relatively low levels (compared with odontocetes and pinnipeds) that have been found in other baleen whale species. However, we note that, because little is known 
regarding potential interactive effects of multiple contaminants, we cannot conclusively rule out an impact, even if levels of individual contaminants were found to be below diagnostic threshold values for other mammals. In addition, the potential impacts of chronic exposure over the life span of this species are unknown.

Although it generally appears that POP concentrations in humpback whale blubber are low, some study areas, particularly the Gulf of Maine and southern California, had whales with $\Sigma$ PCB and $\Sigma$ DDT levels that may warrant further attention. For example, in the NE Gulf of Maine, concentrations of $\Sigma$ PCBs ranged from 4,922 to $51,667 \mathrm{ppb}$ (lipid wt), such that some values exceed the known threshold level for PCB effects on harbor seal immune function $(17,000 \mathrm{ppb})$ [2]. Therefore, the potential for negative health effects for humpback whales from these areas cannot be eliminated.

In addition, research on humpback whales that feed off the California coast found lower reproductive rates compared with other North Pacific regions, and elevated contaminants were thought to be a potential causal factor [68]. Data from the present study confirm that some POP levels, particularly ¿DDTs, are high in samples from California. Although concentrations in baleen whales may be low, overall body burdens may be high because of large body size [67]. Therefore, potentially large amounts of contaminants may be transferred to calves during gestation and lactation. Threshold levels for negative effects are likely lower in young animals that are still in development. Further research should focus on determining POP levels in milk and estimating transfer rates from females to calves in areas where contaminants are highest.

\section{CONCLUSIONS}

Levels of five major POP groups varied among humpback whales from different feeding regions. Data from the present study indicate that, although humpback whales are highly migratory, POP levels in their blubber appear to reflect concentrations in their feeding areas. This provides further evidence that humpback whales show strong site fidelity to feeding regions, and holds promise for using POPs as chemical markers for understanding the population structure of this species. Apart from feeding location, age was shown to influence levels of $\sum$ PCBs, $\sum$ DDTs, and $\sum$ chlordanes significantly. Other factors such as diet are likely important in interpreting POP burdens in humpback whales. Overall, contaminant levels detected in humpback whales were generally lower than in odontocete cetaceans and pinnipeds. Although an assessment of potential health impacts of POPs on humpback whales is difficult, areas that showed elevated POP concentrations and may warrant further study are the Gulf of Maine and southern California. In most other study regions, POPs were low and likely do not represent a significant conservation threat to whales feeding in these areas.

\section{SUPPLEMENTAL DATA}

Table S1. Collection date, region, geographic coordinates, and age for humpback whale samples analyzed.

Table S2. Geometric mean concentration ( \pm standard error) and range of persistent organic pollutants (ng/g, wet wt) in blubber biopsy samples for humpback whales by region. (196 KB DOC)

Acknowledgement-The authors gratefully acknowledge the SPLASH Steering Committee and the Provincetown Center for Coastal Studies for access to samples. We thank G. Schorr, T. Chandler, E. Falcone, B. Witteveen, and J. Straley for sample collection and K. Robertson, D. Steele, S. Baker, P. Palsbøll, and M. Bérubé for sex determination of samples. D. Mattila provided fieldwork support for C. Elfes. We are grateful to G. Ylitalo for statistical support, K. Tilbury for lipid analysis, and J. Bolton and E. Falcone for database support. Chemical analyses were funded through the Environmental Assessment Program of the Northwest Fisheries Science Center, U.S. National Marine Fisheries Service. C. Elfes received support from the School of Aquatic and Fishery Sciences and the Washington Cooperative Fish and Wildlife Research Unit. The use of trade, product, or firm names in this publication is for descriptive purposes only and does not imply endorsement by the U.S. Government.

\section{REFERENCES}

1. Reijnders PJH. 1986. Reproductive failure in common seals feeding on fish from polluted coastal waters. Nature 324:456-457.

2. deSwart RL, Ross PS, Vos JG, Osterhaus ADME. 1996. Impaired immunity in harbor seals (Phoca vitulina) exposed to bioaccumulated environmental contaminants: review of a long-term feeding study. Environ Health Perspect 104:823-828.

3. Eriksson P, Jakobsson E, Fredriksson A. 1998. Developmental neurotoxicity of brominated flame retardants, polybrominated diphenyl ethers and tetrabromo-bis-phenol A. Organohalogen Compounds 35: 375-377.

4. de Wit CA. 2002. An overview of brominated flame retardants in the environment. Chemosphere 46:583-623.

5. Ikonomou MG, Rayne S, Addison RF. 2002. Exponential increases of the brominated flame retardants, polybrominated diphelyn ethers, in the Canadian Arctic from 1981 to 2000. Environ Sci Technol 36:1886-1892.

6. Wilkening KE, Barrie LA, Engle M. 2000. Trans-Pacific air pollution. Science 290:65-67.

7. Barrie LA, Gregor D, Hargrave B, Lake R, Muir D, Shearer R, Tracy B, Bidleman T. 1992. Arctic contaminants: sources, occurrence and pathways. Sci Total Environ 122:1-74.

8. Wania F, Mackay D. 1993. Global fractionation and cold condensation of low volatility organochlorine compounds in polar regions. Ambio 22:10-18.

9. Aguilar A, Borrell A, Reijnders PJH. 2002. Geographical and temporal variation in levels of organochlorine contaminants in marine mammals. Mar Environ Res 53:425-452.

10. Calambokidis J, Steiger GH, Evenson JR, Flynn K, Balcomb KC, Claridge DE, Bloedel P, Straley JM, Baker CS, von Ziegesar O, Dahlheim ME, Waite JM, Darling JD, Ellis G, Green GA. 1996. Interchange and isolation of humpback whales off California and other North Pacific feeding grounds. Mar Mamm Sci 12:215-226.

11. Baker CS, Medrano-Gonzalez L, Calambokidis J, Perry A, Pichler F, Rosenbaum H, Straley JM, Urbán J, Yamaguchi M, VonZiegsar O. 1998. Population structure of nuclear and mitochondrial DNA variation among humpback whales in the North Pacific. Mol Ecol 7:695-708.

12. Calambokidis J, Steiger GH, Straley JM, Hermen LM, Cerchios S, Salden DR, Urban J, Jacobsen JK, vonZiegesar O, Balcomb KC, Gabriele CM, Dahlheim ME, Uchida S, Ellis G, Miyamura Y, Ladrón de Guevara PP, Yamaguchi M, Sato F, Mizroch SA, Schlender L, Rasmussen K, Barlow J, Quinn TJ. 2001. Movements and population structure of humpback whales in the North Pacific. Mar Mamm Sci 17:769-794.

13. Stevick PT, Allen J, Clapham PJ, Katona SK, Larsen F, Lien J, Mattila DK, Palsbøll PJ, Sears R, Sigurjónsson J, Smith TD, Vikingsson G, Øien N, Hammond PS. 2006. Population structuring on the feeding grounds in North Atlantic humpback whales (Megaptera novaeangliae). J Zool 270:244-255.

14. Taruski AG, Olney CE, Winn HE. 1975. Chlorinated hydrocarbons in cetaceans. J Fish Res Board Can 32:2205-2209.

15. Peard J, Calambokidis J. 1981. Chlorinated hydrocarbons in humpback whales (Megaptera novaeangliae) from Southeast Alaska. Report to Sea Search. Cascadia Research Collective, Olympia, WA, USA.

16. Gauthier JM, Metcalfe CD, Sears R. 1997. Chlorinated organic contaminants in blubber biopsies from northwestern Atlantic balaenopterid whales summering in the Gulf of Saint Lawrence. Mar Environ Res 44:201-223. 
17. Metcalfe C, Koenig B, Metcalfe T, Paterson G, Sears R. 2004. Intra- and inter-specific differences in persistent contaminants in the blubber of blue whales and humpback whales from the Gulf of St. Lawrence, Canada. Mar Environ Res 57:245-260.

18. Calambokidis J, Steiger GH, Rasmussen K, Urban RJ, Balcomb KC, Ladron de Guevara PP, Salinas ZM, Jacobsen JK, Baker CS, Herman LM, Cerchio S, Darling JD. 2000. Migratory destinations of humpback whales that feed off California, Oregon and Washington. Mar Ecol Prog Ser 192:295-304.

19. Hoelzel AR, ed. 1991. Genetic Ecology of Whales and Dolphins. International Whaling Commission, Cambridge, UK.

20. Palsbøll PJ, Larsen F, Sigurd-Hansen E. 1991. Sampling of skin biopsies from free-ranging large cetaceans in West Greenland: Development of new biopsy tips and bolt designs. Rep Int Whal Comm 13:71-79.

21. Aguilar A, Borrell A. 1994. Reproductive transfer and variation of body load of organochlorine pollutants with age in fin whales (Balaenoptera physalus). Arch Environ Contam Toxicol 27:546-554.

22. Palsbøll PJ, Vader A, Bakke I, El-Gewely MR. 1992. Gender determination in cetaceans by the polymerase chain reaction. Can $J$ Zool 70:2166-2170.

23. Bérubé M, Palsbøll PJ. 1996. Identification of sex in cetaceans by multiplexing with three ZFX and ZFY specific primers. Mol Ecol 5:283287.

24. Bérubé M, Palsbøll PJ. 1996. Identification of sex in cetaceans by multiplexing with three ZFX and ZFY specific primers:erratum. Mol Ecol 5:283-287.

25. Chittleborough RG. 1965. Dynamics of two populations of the humpback whale, Megaptera novaeangliae (Borowski). Aust J Mar Freshw Res 16:33-128.

26. Sloan CA, Brown DW, Pearce RW, Boyer RH, Bolton JL, Burrows DG, Herman DP, Krahn MM. 2005. Determining aromatic hydrocarbons and chlorinated hydrocarbons in sediments and tissues using accelerated solvent extraction and gas chromatography/mass spectrometry. In Ostrander GK, ed, Techniques in Aquatic Toxicology, Vol 2. CRC, Boca Raton, FL, USA, pp 631-651.

27. Sloan CA, Brown DW, Ylitalo GM, Buzitis J, Herman DP, Burrows DG, Yanagida G, Pearce RW, Bolton JL, Boyer RH, Krahn MM. 2006. Quality assurance plan for analyses of environmental samples for polycyclic aromatic compounds, persistent organic pollutants, fatty acids, stable isotope ratios, lipid classes, and metabolites of polycyclic aromatic compounds NOAA Tech Memo NMFS-NWFSC-77. U.S. Department of Commerce, Seattle, WA, p 30.

28. Ylitalo GM, Yanagida GK, Hufnagle L Jr, Krahn MM. 2005. Determination of lipid classes and lipid content in tissues of aquatic organisms using a thin layer chromatography/flame ionization detection (TLC/FID) microlipid method. In Ostrander GK, ed, Techniques in Aquatic Toxicology, Vol 2. CRC, Boca Raton, FL, USA, pp 227-238.

29. Antweiler RC, Taylor HE. 2008. Evaluation of statistical treatments of left-censored environmental data using coincident uncensored data sets: I. Summary statistics. Environ Sci Technol 42:3732-3738.

30. Brewer CA, Suchan TA. 2001. Mapping Census 2000: The geography of U.S. diversity. Census Special Reports Series CENSR/01-1. U.S. Census Bureau, Washington DC.

31. Breivik K, Sweetman A, Pacyna JM, Jones KC. 2002. Towards a global historical emission inventory for selected PCB congeners - a mass balance approach. 1. Global production and consumption. Sci Total Environ 290:181-198.

32. Li YF. 1999. Global technical hexachlorocyclohexane usage and its contamination consequences in the environment: from 1948 to 1997. Sci Total Environ 232:121-158.

33. Li YF, Cai DJ, Singh A. 1998. Technical hexachlorocyclohexane use trends in China and their impact on the environment. Arch Environ Contam Toxicol 35:688-697.

34. Iwata H, Tanabe S, Sakai N, Tatsukawa R. 1993. Distribution of persistent organochlorines in the oceanic air and surface sea water and the role of ocean on their global transport and fate. Environ Sci Technol 27:1080-1098.

35. Prudente M, Tanabe S, Watanabe M, Subramnian A, Miyazki N, Suarez P, Tatsukawa R. 1997. Organochlorine contamination in some odontoceti species from the North Pacific and Indian Ocean. Mar Environ Res 44:415-427.

36. Li YF, MacDonald RW, Jantunen LMM, Harner T, Bidleman TF, Strachan WMJ. 2002. The transport of $\beta$-hexachlorocyclohexane to the western Arctic Ocean: a contrast to $\alpha-\mathrm{HCH}$. Sci Total Environ 291:229246 .
37. Krahn MM, Herman DP, Matkin CO, Durban JW, Barrett-Lennard, Burrows DG, Dahlheim ME, Black N, LeDuc RG, Wade PR. 2007. Use of chemical tracers in assessing the diet and foraging regions of eastern North Pacific killer whales. Mar Environ Res 63:91-114.

38. Schiff KC. 2000. Sediment chemistry on the mainland shelf of the Southern California Bight. Mar Pollut Bull 40:268-276.

39. Chartrand A. 1988. Montrose Chemical Corporation: Strategies for managing a widespread point source contamination. In Managing Inflows to California Bays and Estuaries. The Bay Institute of San Francisco, Monterey, CA, USA, pp 50-56.

40. Calambokidis J, Barlow J. 1991. Chlorinated hydrocarbon concentrations and their use for describing population discreetness in harbor porpoises from Washington, Oregon and California. NOAA Technical Report NMFS 98:101-110.

41. Westgate A, Tolley KA. 1999. Geographical differences in organochlorine contaminants in harbour porpoises Phocoena phocoena from the western North Atlantic. Mar Ecol Prog Ser 177:255-268.

42. Aguilar A, Borrell A, Pastor T. 1999. Biological factors affecting variability of persistent pollutant levels in cetaceans. J Cetacean Res Manag 1:83-116.

43. Christensen JR, MacDuffee M, MacDonald RW, Whiticar M, Ross PS 2005. Persistent organic pollutants in British Columbia grizzly bears: consequence of divergent diets. Environ Sci Technol 39:69526960.

44. Herman DP, Burrows DG, Wade PR, Durban JW, Matkin CO, LeDuc RG, Barrett-Lennard L, Krahn MM. 2005. Feeding ecology of eastern North Pacific killer whales from fatty acid, stable isotope and organochlorine analyses of blubber biopsies. Mar Ecol Prog Ser 302: 275-291.

45. Chase ME, Jones SH, Hennigar P, Sowless J, Harding CH, Freeman K, Wells PG, Krahforst C, Coombs K, Crawford R, Pederson J, Taylor D. 2001. Gulfwatch: Monitoring spatial and temporal patterns of trace metal and organic contaminants in the Gulf of Maine (1991-1997) with the Blue Mussel, Mytilus edulis L. Mar Pollut Bull 42:491-505.

46. Weisbrod AV, Shea D, Moore M, Stegeman JJ. 2000. Organochlorine exposure and bioaccumulation in the endangered northwest Atlantic right whale (Eubalaena glacialis) population. Environ Toxicol Chem 19:654-666.

47. Paquet D, Haycock C, Whitehead H. 1997. Numbers and seasonal occurrence of humpback whales, Megaptera novaeangliae, off Brier Island, Nova Scotia. Can Field Nat 111:548-552.

48. Payne PM, Nicolas JR, O'Brien L, Powers KD. 1986. The distribution of the humpback whale, Megaptera novaeangliae, on Georges Bank and in the Gulf of Maine in relation to densities of the sand eel, Ammodytes americanus. Fish Bull 84:271-277.

49. Payne PM, Wiley DN, Young SB, Pittman S, Clapham PJ, Jossi JW. 1990. Recent fluctuations in the abundance of baleen whales in the southern Gulf of Maine in relation to changes in selected prey. Fish Bull 88:687-696.

50. Hain JHW, Ellis SL, Kenney RD, Clapham PJ, Gray BK, Weinrich MT, Babb IG. 1995. Apparent bottom feeding by humpback whales on Stellwagen Bank. Mar Mamm Sci 11:464-479.

51. Lawson JW, Magalhães AM, Miller EH. 1998. Important prey species of marine vertebrate predators in the northwest Atlantic: proximate composition and energy density. Mar Ecol Prog Ser 164:13-20.

52. Saether O, Ellingsen TE, Mohr V. 1986. Lipids of North Atlantic krill. J Lipid Res 27:274-285.

53. Krieger KJ, Wing BL. 1986. Hydroacoustic monitoring of prey to determine humpback whale movements NOAA Tech Memo NMFS F/ NWC-98. National Oceanic and Atmospheric Administration, Auke Bay, AK, USA, p 62

54. Nemoto T, Kawamura A. 1977. Characteristics of food habits and distribution of baleen whales with special reference to the abundance of North Pacific sei and Bryde's whales. Rep Int Whal Comm 1:80-87.

55. Witteveen B, Foy R, Wynne K, Tremblay Y. 2008. Investigation of foraging habits and prey selection by humpback whales (Megaptera novaeangliae) using acoustic tags and concurrent fish surveys. Mar Mamm Sci 24:516-534.

56. Barron MG, Heintz R, Krahn MM. 2003. Contaminant exposure and effects in pinnipeds: implications for Stellar sea lion declines in Alaska. Sci Total Environ 311:111-133.

57. Witteveen BH, Worthy GAJ, Wynne KM, Roth JD. 2009. Population structure of North Pacific humpback whales on their feeding grounds revealed by stable carbon and nitrogen isotope ratios. Mar Ecol Prog Ser 379:229-310 
58. O’Hara TM, Krahn MM, Boyd D, Becker PR, Philo LM. 1999. Organochlorine contaminant levels in Eskimo harvested bowhead whales of arctic Alaska. J Wildl Dis 35:741-752.

59. Hoekstra PF, O’Hara TM, Pallant SJ, Solomon KR, Muir DCG. 2002. Bioaccumulation of organochlorine contaminants in bowhead whales (Balaena mysticetus) from Barrow. Alaska. Arch Environ Contam Toxicol 42:497-507.

60. Kleivane L, Skaare JU. 1998. Organonochlorine contaminants in northeast Atlantic minke whales (Balaenoptera acutorostrata). Environ Pollut 101:231-239.

61. Aguilar A, Borrell A. 1988. Age- and sex-related changes in organochlorine compound levels in fin whales (Balaenoptera physalus) from the eastern North Atlantic. Mar Environ Res 25:195-211.

62. Willett KL, Ulrich EM, Hites RA. 1998. Differential toxicity and environmental fates of hexachlorocyclohexane isomers. Environ Sci Technol 32:2197-2206.

63. Oehme M, Schlabach M, Kallenborn R, Haugen JE. 1996. Sources and pathways of persistent polychlorinated pollutants to remote areas of the
North Atlantic and levels in the marine food chain: a research update. Sci Total Environ 186:13-24.

64. Wolkers H, van Bavel B, Derocher AE, Wiig Ø, Kovacs KM, Lydersen C, Lindström G. 2004. Congener-specific accumulation and food chain transfer of polybrominated diphenyl ethers in two Arctic food chains. Environ Sci Technol 38:1667-1674.

65. Robbins J. 2007. Structure and dynamics of the Gulf of Maine humpback whale population. PhD thesis. University of St. Andrews, St. Andrews, UK.

66. Aguilar A, Borrell A. 1990. Patterns of lipid content and stratification in the blubber of fin whales (Balaenoptera physalus). J Mammal 71:544 554.

67. O'Shea TJ, Brownell RL. 1994. Organochlorine and metal contaminants in baleen whales: a review and evaluation of conservation implications. Sci Total Environ 154:179-200.

68. Steiger GH, Calambokidis J. 2000. Reproductive rates of humpback whales off California. Mar Mamm Sci 16:220-239. 